\title{
Looking beyond the individual
}

Citation for published version (APA):

Cleland, J., \& Dolmans, D. (2017). Looking beyond the individual: Quality research requires supportive environments. Medical Teacher, 39(9), 904-905. https://doi.org/10.1080/0142159X.2017.1309012

Document status and date:

Published: 01/01/2017

DOI:

10.1080/0142159X.2017.1309012

Document Version:

Publisher's PDF, also known as Version of record

Document license:
Taverne

\section{Please check the document version of this publication:}

- A submitted manuscript is the version of the article upon submission and before peer-review. There can be important differences between the submitted version and the official published version of record.

People interested in the research are advised to contact the author for the final version of the publication, or visit the DOI to the publisher's website.

- The final author version and the galley proof are versions of the publication after peer review.

- The final published version features the final layout of the paper including the volume, issue and page numbers.

Link to publication

\footnotetext{
General rights rights.

- You may freely distribute the URL identifying the publication in the public portal. please follow below link for the End User Agreement:

www.umlib.nl/taverne-license

Take down policy

If you believe that this document breaches copyright please contact us at:

repository@maastrichtuniversity.nl

providing details and we will investigate your claim.
}

Copyright and moral rights for the publications made accessible in the public portal are retained by the authors and/or other copyright owners and it is a condition of accessing publications that users recognise and abide by the legal requirements associated with these

- Users may download and print one copy of any publication from the public portal for the purpose of private study or research.

- You may not further distribute the material or use it for any profit-making activity or commercial gain

If the publication is distributed under the terms of Article $25 \mathrm{fa}$ of the Dutch Copyright Act, indicated by the "Taverne" license above, 


\title{
COMMENTARY
}

\section{Looking beyond the individual: Quality research requires supportive environments}

\author{
Jennifer Cleland ${ }^{\mathrm{a}}$ and Diana Dolmans ${ }^{\mathrm{b}}$ \\ ${ }^{a}$ Centre for Healthcare Education Research and Innovation (CHERI), Institute of Education for Medical and Dental Sciences, University of \\ Aberdeen, Aberdeen, UK; ${ }^{b}$ School of Health Professions Education (SHE), Maastricht University, Maastricht, The Netherlands
}

This issue of Medical Teacher includes an article by ten Cate and colleagues which focuses on defining excellence in health professions education PhD dissertations. The authors point out that $\mathrm{PhD}$ programs in health professions education (HPE) are becoming increasingly popular yet they argue that excellence in $\mathrm{PhD}$ dissertations has not been well defined. Thus, their article proposes generic criteria by which to evaluate the excellence of individual $\mathrm{PhD}$ dissertations, including, for example, coherence, relevance, validity, style, communicative power and ethics.

However, as noted by ten Cate and colleagues, PhD dissertations are products of collaborations. Thus, we make a plea that we should look beyond the individual. Given that "no man is an island, entire of itself" (John Donne, 1624), supporting quality research requires harnessing the motivation, drive and professional development of an individual scholar/dissertation within the wider context of the mesolevel of the academic unit and the macro-level of the institution within which a unit is situated. Instead of looking at the individual level of a PhD, it is also important to look at research quality at an entire unit or institute. Supporting quality research depends on creating an organizational culture which values continuous improvement of a supportive environment for research and innovation.

But what are the characteristics of such a supportive environment? Our views on this are grounded in the perspective that a PhD trajectory is first and foremost a learning trajectory aimed at preparing a PhD to conduct independent good research as per the ORPHEUS standards http://www.orpheus-med.org/images/stories/documents/ ORPHEUS-AMSE-WFME-standards-for-PhD-education.pdf.

First, such a program must include formalized courses: researchers within the HPE domain often have limited knowledge about research within the social sciences (Albert et al. 2007) and need to be trained to be able to contribute to the body of scientific knowledge within our field. PhDs looking to join a unit should ask questions such as: Does the unit or institution stimulate participation in formal PhD training courses covering a broad spectrum of thematic, methodological and more generic courses (i.e. workshops or courses related to academic writing, research integrity, data management, career planning, preparing grant applications, etc.)? More informally, are staff and students also encouraged to develop their research and innovation knowledge and skills (via, for example, adequate supervision, journal clubs, guest seminars, internal and external networking opportunities)? Given the increasing emphasis on impact of research, does the unit or institution support staff to give presentations for general audiences, to publish not only in international journals, but also in professional journals, and to engage with external partners to ensure their work contributes beyond academic, to have societal relevance?

Second, the unit or institution must be able to attract and retain qualified staff. It should support staff to apply for funding streams to seed fund pilot and/or collaborative studies designed to initiate a program of research that contributes to high-quality research with both theoretical and practical relevance. Critically, time allowance is needed for "scholarship" included in workload planning, to engage in research and innovation activity. If this is not the case, then even enthusiastic individuals will struggle to move beyond "one off" studies to work on coherent, accumulative programs of research (Rogers 2011). It is also important to establish promotion and tenure systems so staff are recognized and valued for their HPE research and innovation achievements. One way of doing this, embedded in our own institutions, is to have diverse but equivalent career tracks to reflect the different balance of activities undertaken by colleagues at the University, including Teaching and Scholarship, and Teaching and Research within a unit or institution.

Third, a strong unit has a critical mass of HPE research staff who are internally and externally visible and are well prepared for the future because they have a good succession planning strategy to ensure sustainable contributions to the field. This can be daunting, and it is fair to say that there are only a few centers around the world which have achieved a critical mass. However, just as it takes time to become an expert in anything, it also takes time for units to establish themselves, before consolidating and expanding on their areas of strength. And there are ways and means for emerging and smaller centers to facilitate research and innovation. For example as I (JC) build my own unit, I spend a lot of time on the following activities. First, I engage upwards within my own institution to ensure those in positions of power know about our achievements. I have taken care to ensure my unit's mission and vision fit with those of the wider organization, so our achievements can map onto the university's goals (for example, in terms of increasing diversity within the medical student body, and developing strategies to attract high quality healthcare 
workers to the region). Over time, this has gained my unit concrete resources, as well as the less tangible, but highly important gains, of being visible and well-regarded internally (Bourdieu 1986). I engage outwards with a vibrant network of national and international colleagues, and external organizations. This has led to numerous collaborations, including inviting external colleagues to co-supervise HPE research dissertations. This "win-win" system which works very well in terms of compensating for current skills and knowledge gaps in my team, expanding our international and interdisciplinary research presence and profile - and gives our partners a formal, international research partnership. I spend much time ensuring that junior and midlevel staff are mentored and supported in their professional development, including working towards the achievement of their HPE research dissertations.

Four, following the above, our observation is that at the core of effective capacity building is unflagging energy, motivation, commitment, tenacity, and the skill to maintain focus while being sufficiently flexible to take advantage of unexpected opportunities, and respond to unanticipated change. Yet the insight that the stewardship of any one individual, no matter how renowned, is fleeting is also crucial -the long-term sustainability of an HPE research unit depends on succession planning. Units need to offer career paths to those with high potential, such as highly qualified $\mathrm{PhD}$ candidates, the future leaders of our field.

In conclusion, we believe that supporting quality HPE research is a function of the integration and interplay of individual and institutional factors. An environment which supports individuals to produce high quality, socially relevant HPE dissertations via training, opportunities and a scholarly culture will attract excellent PhDs. Excellent PhDs enhance a unit's reputation, which in turn attracts staff, students and opportunities to continue to make sustainable contributions to science and society. In short, excellent research is the result of the interplay between the individual and the context, supporting quality research depends on creating an organizational culture which values continuous improvement of a supportive environment for research and innovation.

\section{Disclosure statement}

The authors report no conflicts of interest. The authors alone are responsible for the content and writing of this article.

\section{Notes on contributors}

Jennifer Cleland, $\mathrm{PhD}$, is a professor in medical education research at the University of Aberdeen, UK. Her research focuses on selection, assessment and performance, and medical careers decision making.

Diana Dolmans, $\mathrm{PhD}$, is a professor in the field of innovative learning arrangements at Maastricht University, the Netherlands. Her research focuses on the key success factors of innovative curricula within higher education in general and problem-based learning in specific.

\section{References}

Albert M, Hodges B, Regehr G. 2007. Research in medical education: balancing service and science. Adv Health Sci Educ Theory Pract. 12:103-115.

Bourdieu P. 1986. 'The forms of capital. In: Richardson JG, editor. Handbook of theory and research for the sociology of education. New York: Greenwood Press, pp. 241-258.

Rogers DA. 2011. Advancing surgical education scholarship. Am J Surg. 201:1-6. 